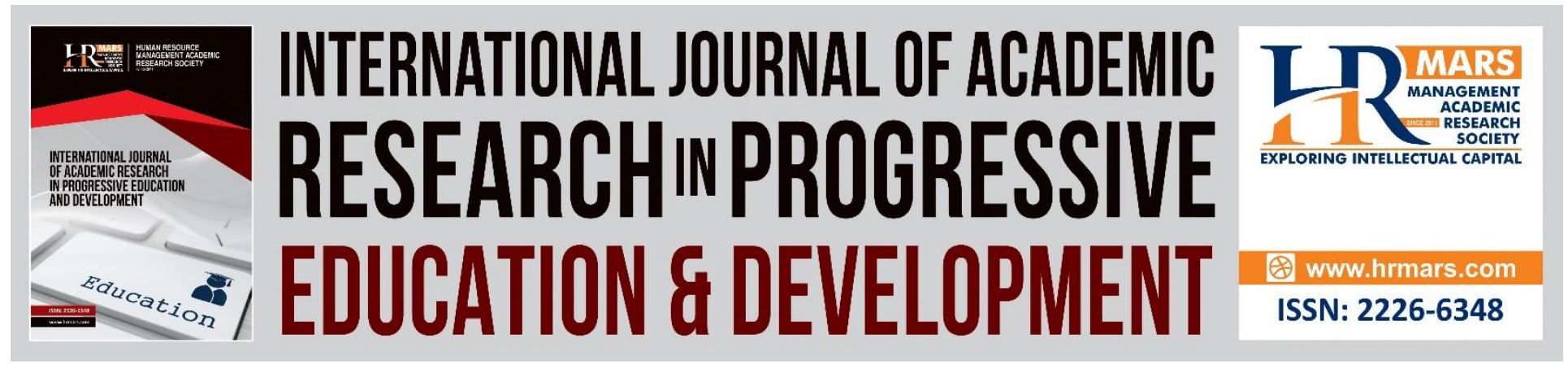

\title{
Learning Theories: Views from Behaviourism Theory and Constructivism Theory
}

\begin{abstract}
Nur Aimi Nasuha Burhanuddin, Nor Aniza Ahmad, Rozita Radhiah Said \& Soaib Asimiran
\end{abstract}

To Link this Article: http://dx.doi.org/10.6007/IJARPED/v10-i1/8590

DOI:10.6007/IJARPED/v10-i1/8590

Received: 03 January 2021, Revised: 28 January 2021, Accepted: 12 February 2021

Published Online: 26 February 2021

In-Text Citation: (Burhanuddin et al., 2021)

To Cite this Article: Burhanuddin, N. A. N., Ahmad, N. A., Said, R. R., \& Asimiran, S. (2021). Learning Theories: Views from Behaviourism Theory and Constructivism Theory. International Journal of Academic Research in Progressive Education and Development, 10(1), 85-98.

Copyright: (C) 2021 The Author(s)

Published by Human Resource Management Academic Research Society (www.hrmars.com)

This article is published under the Creative Commons Attribution (CC BY 4.0) license. Anyone may reproduce, distribute, translate and create derivative works of this article (for both commercial and non-commercial purposes), subject to full attribution to the original publication and authors. The full terms of this license may be seen at: http://creativecommons.org/licences/by/4.0/legalcode

\section{Vol. 10(1) 2021, Pg. 85 - 98}

http://hrmars.com/index.php/pages/detail/IJARPED

JOURNAL HOMEPAGE

Full Terms \& Conditions of access and use can be found at http://hrmars.com/index.php/pages/detail/publication-ethics 


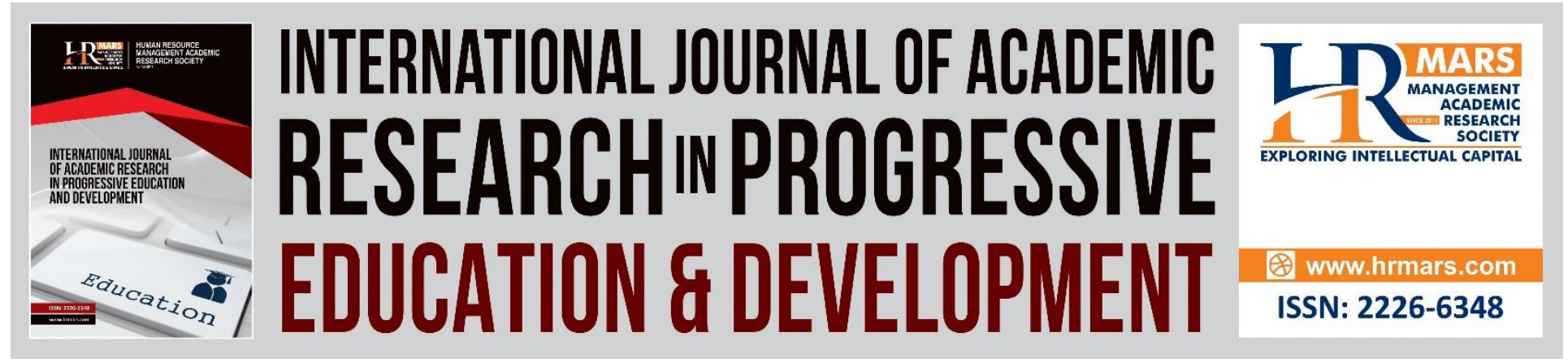

\title{
Learning Theories: Views from Behaviourism Theory and Constructivism Theory
}

\author{
Nur Aimi Nasuha Burhanuddin, Nor Aniza Ahmad, Rozita \\ Radhiah Said \& Soaib Asimiran \\ Department of Foundations of Education, Faculty of Educational Studies, Universiti Putra \\ Malaysia, 43400 Serdang Selangor \\ Email: nor_aniza@upm.edu.my
}

\begin{abstract}
Scholars, psychologists and pedagogues like Al-Ghazali, Skinner, Piaget, Vygotsky and others give us an opportunity to have an insight into: 1) How to re-think education; 2) What is the most comprehensive way for a learner to learn?; 3) Imagine a new environment that can give a better future especially for a growing child. They are the people who remind us that learning always involve interaction with other people, submitting ourselves to other people's ideas or values not just by ourselves. This article presented some of these great scholar and psychological theory and ideas while also discussed their contribution, the differences and at the end how those theories interconnected between one another.
\end{abstract}

Keywords: Learning Theory, Psychological Theory, Constructivism, Behaviourism, Pedagogy

\section{Prelude}

Much of learning theories we know and probably used in our studies are focusing on the western theories of learning. Little that we know, some of the elements in the theories brought up by western psychologist somehow converged at points with Islamic scholar's view, specifically AlGhazali's. In this article, I do not advocate one approach over another. However, I am comparing the idea of learning theories brought up by western psychologists between behaviourism theory and constructivism theory and how at certain points, their idea collides with Al- Ghazali's perspective. In this writing, the position I put myself into, either behaviourism or constructivism is strongly related to the strong belief I have in Al-Ghazali's teachings. I would like to emphasize here that there is nothing wrong with the position that I am not sided with, which is constructivism, it is just that the theory is less frequently similar than behaviourism theory. Yet, the similarities held by both behaviourism and constructivism which both deal with interaction was even mentioned by Al-Ghazali. My own interest with behaviourism grows out of a personal belief that base on the teaching of the great educator of Islam, Imam Al-Ghazali. 
Scholars, psychologists and pedagogues like Al-Ghazali, Skinner, Piaget, Vygotsky and others give us an opportunity to have an insight into: 1) How to re-think education, 2) What is the most comprehensive way for a learner to learn? 3) Imagine a new environment that can give a better future especially for a growing child. They are the people who remind us that learning always involve interaction with other people, submitting ourselves to other people's ideas or values not just by ourselves.

In this writing, I present some of these great scholar and psychologist theory and ideas. I will discuss what each contributes, what are the differences and at the end how the theories interconnected between one another.

\section{Imam Al-Ghazali (1059-1111 AD)}

Though his teaching is not my main focus in this writing, as my beliefs is deeply rooted from his perspective, I will briefly introduce him and describe this great scholar's teaching and throughout this essay, I will make a synchronize comparison with behaviourism and constructivism theory of learning. To start with, in the Islamic theory of knowledge, 'ilm is the term in Arabic use for knowledge. Knowledge in the western world means facts, information, and skills acquired through experience or education; the theoretical or practical understanding of a subject. While 'ilm (knowledge) as according to Imam Al- Ghazali is the term encompass education, theory, and action. Not only that, he added, knowledge can bring us closer to God as well as enhance worldly respect and position (Faris, 1962; Al-Abrasy, 1973). Knowledge is not relative but has an entity in itself. It can raise the status of the individual, create self-respect and take him to the highest position. He emphasized that knowledge is information gathered either through five external senses; sight, hearing, taste, smell and touch or the five internal senses; imagination, recollection, reflection, memory and common sense. In addition, knowledge is acquired by learning and deduction, as for example, two plus two equal to four or through inference such as reflection (Scallie, 2010). Acquired knowledge deals either with the present world, such as the arts and sciences or the next world such as knowledge of the heart, god and his attributes. The power of the intellect cannot master the knowledge of both worlds, as it can cause tension. Lastly, according to him knowledge can also be flung into the heart without acquisition or proof and this is called General Inspiration. This is the way Prophets and Saints had the divine inspiration revealed to them, not by learning and studying but by cutting off ties with the present world, emptying the heart and advancing wholeheartedly toward god (Scallie, 2010). As a whole, Imam Ghazali's aim of knowledge is that the knowledge gained as a result of education should be useful for both individual and the society. Education serves as a medium for character building so that it could differentiate between good and evils and thus avoid from following the evil path (Al-Abrasy, 1973). Before I start the discussion, I would like to emphasis here that the purpose of introducing Imam Al-Ghazali's background is not to raise third position from those who have contributed in learning theory but, serves to relate some of the aspects in behaviourism and constructivism to the teaching of Al- Ghazali in which like I have previously said, where my stand to behaviourism stemmed from. 


\section{Introduction}

In this writing, there are a number of broad questions reflecting on both learning theories that I want to focus on which is behaviourism theory and constructivism theory. How the learning process is viewed? What is the locus of the learning? What is the purpose of the theories to education? To what extent do these theories being implemented in our lives? These questions will be answered by exploring each of the elements that compromise in both learning theories. I will view and try to demystify the approach adopted in both learning theories in relation to epistemology, ontology and also methodology.

To start with, I shall first introduce the person who dominate and contributed greatly in both theories. For behaviourism theory, the behaviourists are B.F. Skinner, Ivan Pavlov, Edward Thorndike, John B. Watson, Edwin Ray Guthrie, Clark Leonard Hull and Edward C. Tolman. Meanwhile for constructivism theory, Jean Piaget, John Dewey, Lev Vygotsky, David Boud and Barbara Rogoff are the person or I shall say constructivist who dominate the field and have contributed immensely to construct this theory. In this writing, I am not going to discuss in detail about each of the behaviourists/constructivist and their view about behaviourism and constructivism theory but focused only on the work done by some of them.

\section{Behaviourism Theory}

Behaviourism theory view learning and education as the change in behaviours of an individual and throughout the process, it involves some exploration, trial and error until a positive event occurred. Behaviourists pay no attention to what is happening inside the learner as according to their point of view, what is happening inside are not available to be observe directly (Watson, 1913). This theory highlight that the participation of the learner is stimulusresponse process, largely a passive and knowledge is seen as factual, specified and rigid. Behaviourist Skinner underlines four important things about learning. First is that, each step in the learning process should be concise and continuous from previously learned behaviour. Secondly, for an effective learning process, students should be rewarded and reinforced consistently, at least at early stages until the behaviour is shaped by the pattern of reinforcement in the environment. Third, immediate feedback should be given to the learner. Lastly, the learner should be given 'stimulus-discriminations' for the most likely path to success (Skinner, 1984).

\section{Constructivism Theory}

Constructivism as paradigm or worldview hypothesize that learning is active and constructive process. Information received by the learner is constructed throughout the journey of learning. According to this theory, people will actively construct knowledge according to their own understanding about reality. New information is linked to a previous knowledge thus mental representation are subjective (Applefield et al., 2001). Here, I would like to bring upon constructivism theory from Jean Piaget's perspective and how he theorised it. He who is known for his extensive research on developmental psychology explained that a series stages must be passed through and experienced by the children which requires schemes, in which structuring the information received and understand how it works, assimilation, take in and understand fully new information received into schemes and accommodation which works by transforming 
existing schemes or creating new ones (Piaget, 1953). A continuous interaction within these process, schemes, assimilation and accommodation, concrete experience will be organized into patterns of behaviour that eventually internalised to become 'abstract models' or 'schemata' (Wadsworth, 2004; Semple, 2000).

\section{Behaviourism and Constructivism; The Locus of Learning}

The first perspective that I would like to dwell deeper from both behaviourism theory and constructivism theory are from the locus of the learning. Both theories are very distinctive from one another in this aspect. While behaviourism involved the work of stimuli in external environment, constructivism on the other hand involves the internal construction of reality by individual. In a nutshell, behaviourism views learning as something that occurs from the outside of a person to inside while constructivism occurs the other way around, which is from the inside of a person to outside. As mentioned earlier, behaviourism theory is the concept that operates based on the principle of 'stimulus-response'. All behaviours portrayed by a person are caused by external stimuli (Watson, 1930). Behaviourist also added that a person's internal mental states or consciousness does not need to be considered to explain someone's behaviour. In addition, this theory assumes that passive and responding to environmental stimuli is the nature of a learner. The learner always starts off as a clean slate (Tabula rasa) and behaviour is then will be shaped through positive/negative reinforcement or punishment (Watson, 1913). Positive and negative reinforcement responsible in the change of behaviour and at the same time increase the probability that the previous behaviour to happen again. However for punishment, both negative and positive responsible in the decrease of previous behaviour to happen again. Positive behaviour implies the application of stimulus while negative behaviour implies the withholding of stimulus (Watson, 1930). This is similar to what Al-Ghazali states in his teaching. He used seeds as a metaphor to explain his view. He said, 'Human beings are imperfect creatures and are similar to seeds. They have the capacity and ability to become perfect, however it only happens when there is a suitable condition provided'. To draw a close, the locus of learning in behaviourism theory revolves around the change in behaviour with the involvement of stimulus in external environment as an indicator that one's behaviour has shifted to whether a positive or negative side. When we compare with locus of learning from constructivism perspective, it is a theory that emphasize about the internal construction of reality by individual. Again, to simplify this, like I have mentioned before the learning process occur from the inside of a person to outside. The learning process was constructed naturally from the person itself and, rather than acquiring, learning is actually a process of constructing knowledge. Knowledge will be constructed based on the personal experiences and hypotheses of the environment. These hypotheses will be continuously test by the learner through social negotiation. Now, looking at this point, not only behaviourism has the similarity with Al-Ghazali's teaching, but constructivist also shared the same view in certain areas. One of the sections in Al- Ghazali's book writes about the 'Method of Teaching and The Techniques', he states that, for the learning process to occur, teaching session should be based on the prior knowledge and experiences of the students. Not only this helps the students in their learning process, but at the same time it helps the teacher itself to know the ability, knowledge and aptitude of the learner thus can assist and give motivation to the students towards the lesson, which is very crucial for educational process. This serves to explain how 
important the experiences are for the learning process to take place when two great scholars mentioned in their theory. Another interesting point raised by constructivist is that the knowledge has its own interpretation and construction according from the person's self and it is different from every person. The learner is not a blank slate (Tabula rasa), however they bring the past experiences and cultural factors to make a meaning of what will they interpret and construct later on. This statement is contradicted with what behaviourism and Al-Ghazali's theory. To understand how constructivism theory functions, I will now use Jean Piaget's works to explain.

Piaget's theory provides a solid framework about what children do and how they think at different stages of their development. To Piaget, children understand the world from their own views and their views are extremely robust, coherent and continually evolving. Their ways of thinking are very much different from adult's. Children's ways of thinking and doing have an honesty, a logic of its own, that most of the time is well suited to their current needs and possibilities. Children can view the world from a spectrum perspective thus making their way of thinking form such complexity. However, Piaget did emphasised that knowledge are constructed internally, always expand and plateaus from within according to complex laws of selforganization. Piaget's view of education has grave repercussion such that; Firstly, teaching is always indirect. This brings a meaning that children with their complex mind did not just accept the information they received and what's being said by others instead, they interpret the information based on their own understanding according to their knowledge and experiences. Secondly, to Piaget, the process of gaining knowledge is through interaction with the world, people and things. Not something that is delivered at one end. Simultaneously, experience is constructed while the process of acquiring knowledge is happening. Lastly, resistances to learning should not be ignored. Piaget has proved that the influence children received from outside while on their journey to adulthood helped their process of learning. This is because through the process, children will experience new things and they will deal with conceptual difficulties and that is what makes them become mature. Piaget's theory concerned about children and focused on development rather than learning per se. He demonstrates in his theory how development process of a children is strongly connected to their learning process hence more compelling methods in teaching can be applied. Piaget (1972) in his work explores four sequential stages of the psychological development of the young leaner and he believes that teacher should be conscious of these stages. The first stage is The Sensory-Motor Stage. This stage extends from birth until the age of two. This is the stage where senses, reflexes and motor abilities develop rapidly that enables children to acquire knowledge and experiences. Child intelligence consist of basic motor and sensory exploration of the world such that it was display when reflex movement become more refines. The example of it could be when the infant chooses to reach for preferred toys when they play. The infant understands the world only with perception and the object that they have directly experienced before. Most of the time, they discovered their actions through incidents happened and they will repeat it and apply to new situations in order to get the same results. At this point of development, Piaget believes that the understanding about the objects continue to exist even when they cannot see it. The next stage is preoperational stage, a stage where the children are not yet able to think logically and learn through pretend play. This occurs 
at the age of two until seven. They represent the world through mental images and symbols with the help of language acquisition. However, these symbols depend on their own perception and intuition. Regardless that they have already shown an interest in objects and people around them, a child who is on this stage is completely egocentric and everything is sees from only one point of view, which is their own. This is the age of curiosity where they questioned everything and constantly investigate new things. They make up explanation on their own when they don't have one since they only know the world from their limited experiences and perspective. It is during this preoperational stage that children think differently from most of the adult. Following this stage is the stage of concrete operations. This stage occurs when the children is at the age of seven until eleven. At this stage, the child begins to think more logically and perform mental operations. Through mental operation, a child constantly makes sense about the previous action they have performed. Their way of thinking at this point is very firm. At this stage, they are struggling with abstract and hypothetical concepts. Nevertheless, they become less egocentric and stop thinking just only from their point of view, about themselves. They start to think about other people. The last stage is the formal operational stage. This final stage of Piaget's theory occurs at the age of eleven until sixteen. This is the stage where children's logical thinking increase, they start to understand the abstract ideas, and able to use deductive reasoning. At this point, they are capable of finding solutions to problems and can think in a more scientific way to explain what is happening around them. This Piaget's theory of stages has made a lot of contributions where through his theory, learning process are designed so that they are parallel with children's cognitive development.

Piaget's work has an enormous influenced on educational thinking and on the development of education. Nevertheless, there is still a criticism reported on his theory in which he did not take into account the influence of cultural transmission and the effect of social interaction. This is because according to social or Vygotskian constructivism, individual construct knowledge in exchange with the environment and in the process, both are changed. Vygotsky added, the functions that at first appear as social phenomena would later become internalized as psychological phenomena (Boyle, 1997). Social constructivist Vygotsky believes that for children to develop cognitively in a context of socialization and education, both learning and development need to be collaborated. Vital cognitive tools provided by culture such as social context, history, traditions, language, culture and religion are responsible in transforming children's attention, perceptual, and memory capacities. Children need an interaction with social environment on an interpersonal level and then internalized the experiences gained to enable learning process to occur. The earlier notions and new experiences influence the children who then construct new ideas (Vygotsky, 1978). Rather than conflicting, the two theories, psychological and social constructivist theories are complementary each other as they both emphasize the role of interaction and constructive development process in learning even though the nature of the interaction is different in each. In comparison to behaviourism theory proposed by behaviourist, constructivist view learning as an active process rather than passive process. Apart from that, though constructivism theory is said to be so context-dependent and shies away from formalized plan in educational practice, constructivist principles about learning do emerge and have bearing on practice (Greening, 1998). The principles are summarized as follows: 
Vol. 10, No. 1, 2021, E-ISSN: 2226-6348 @ 2021 HRMARS

- The learner construct knowledge from experiences

- Rather than externally, knowledge resides in the mind of the learner

- Learner interpret objects and events through their beliefs and value in the process of learning as their personal interpretation of the world.

- Through experiences, learner constructs meaning out of it as part of their learning process.

- Learning takes place in contexts relevant to the learner.

- Essential part of learning includes learner's reflection to the world.

- Multiple perspectives are considered to make learning as a collaborative process.

The principles outlined above encapsulate the broad idea of constructivism and how the process took place in learning and educational setting. We will next explore in detail on how this constructivism theory diversify in a way that the learning process is view, and what is the purpose of this theory to education. This exploration will provide and lead us to a better understanding of this theory.

\section{Behaviourism and Constructivism; View of Learning Process}

Learning process in behaviourism occurs in such a way that it resulted in the change of behaviour of a person. Reinforcement theory developed by behaviourist B.F Skinner plays a significant role in explaining this occurrence (Laird 1985; Burns, 1995). Skinner believes that one's behaviour is the result from an action previously done. If positive reinforcement follows the behaviour, the learner will have the tendency to repeat the desired behaviour. There are many ways positive reinforcement can be done. This included when using verbal reinforcement such as "That is right", "That is good", or "You are doing the right thing". In addition, this kind of reinforcement can also be presented through a clear-cut reward such as giving some kind of acknowledgement when successfully manage to attend schools without a day misses throughout school session. Not only positive reinforcement works in strengthen someone's behaviour, negative reinforcement will also give the same result. This refers to a situation when negative condition is stopped or avoided as consequences of behaviour. The example for negative reinforcement can be such as, a student has to pay a teacher $f 5$ when he/she failed to complete homework given. This is opposite to how positive reinforcement works. In positive reinforcement, a teacher will be the person who gives students $f 5$ when he/she succeeded in completing the homework given. Both positive and negative reinforcement resulted in a change of unpleasant or pleasant behaviour to a behaviour that has a tendency to be repeated. In contrast, another aspect in reinforcement theory that is punishment, will result in weaken one's behaviour. This is because the condition introduced and experienced by the individual teaches them to not repeat the same behaviour again as it was negatively reinforced. The main purpose of punishment is to create a condition that eventually will put an end to one specific unfavorable behaviour (Burns, 1995, p 108). Laird (1985) views this aspect of behaviourism as irrelevant to education. This scope of behaviourism was also mentioned by Al-Ghazali in his teachings. According to him, affection is required in learning process (Arifin, 1991). Teacher who students see as their role model should avoid using the force. They should be like a mother/father to their students and should use love and affection instead of punishment. The use of force can lead and 
result to bad habits among the students. This is because, education according to Al-Ghazali is, "Omitting bad morals and planting the good one. Thus, education is a process of systematic activity to create progressive changes on human behaviour" (Bigot, 1957).

When looking at constructivism, constructivists view the learning process as construction of meaning from experiences. Piaget wrote, "The subject exists because, to put it briefly, the being of structures consists in their coming to be, that is, their being 'under construction'. There is no structure apart from construction" (Piaget, 1970, p.140). To all intents and purposes, Piaget who viewed organism as a whole system believed that human simultaneously developed in a cognitive sense aside from a physical and biological sense. According to him, human is a structure constructed with cognitive, emotional and physical development. In much of his research, he promotes change in cognition was the same as in evolution-equilibration. He described equilibration as one dynamic process of self-regulated behaviour balancing two intrinsic polar behaviours, as mentioned briefly before, assimilation and accommodation. Assimilation is a process of organizing an experience. It constitutes individual's tendency to view, understand, and act on the surroundings. Piaget explains that through times, this process results as one evolves while searching for new knowledge and encounter 'new territory'. Meanwhile for accommodation, it comprised of reflective, integrative behaviour that responsible to change one's own self and analyses the object in order to function with cognitive equilibrium in relation to it. In Equilibration of Cognitive Structures (1977), Piaget explained that his "...earlier model had proved insufficient and that his central new idea is that knowledge proceeds neither solely from the experience of objects nor from an innate programming performed in the subject but from successive constructions" (preface, p. v).

In order for a successive construction to happen, he proposed constructivist classroom called 'The Piagetian Classroom'. Piaget believes that this kind of classroom can be a medium for students to construct their knowledge while at the same time encourage them to discover new ideas, increase their readiness to learn and also for students to accept individual differences. Through this process, in line with what Piaget state in Equilibration of Cognitive Structures (1977), which has already mentioned previously, experiences can be built parallel to the innate programming performed within subject (students). The example of his idea of classroom involves the use of videodisk, CD-ROMs and simulation software which functions to enhance learning. Meanwhile, for the construction of knowledge, telecommunication tools such as e-mail and Internet should be used to provide contexts for dialogue and to connect with community surroundings. When these aspects are being implemented, student's knowledge and ideas will broaden to the extent of global issues. Concrete learning experiences such as drama, drawing, model building and field trips are suggested for Piagetian elementary classroom so that students are actively involved in hands-on opportunities to hear, see, touch, taste and smell. Those sensory systems according to Piaget are essential for an ideal learning process to occur. In addition, these early activities and visual aids serve as building blocks for a more sophisticated task in future. Social constructivist, Lev Vygotsky idea of classroom however, emphasizes on creating one's own concept and making knowledge of one's property. This requires the learning to take place in a conducive and meaningful context, together with the learning in the real world. 
Similar with Piagetian classroom, Vygotskian classroom also focused on interactive learning throughout the learning process. The idea is to create teacher-student and student-student interaction in the classroom thus forming a social interaction within the circle of community and eventually help the learning process. In Vygotskian classroom, considerate guidance and dynamic support are provided to the student based on their needs without any will or force. Students should be exposed to discussion, research collaboration and group work project. The ideal classroom proposed by both constructivists Piaget and Vygotsky are leading towards the idea of constructivism itself that is to construct a meaning from experiences that the students gained throughout the process. Along the journey of learning, students will construct the experiences that they have collected and make a meaning out of it thus, will understand the world better.

\section{Application of Behaviourism and Constructivism to Education}

It is important to emphasis again that learning has a strong connection in the change of behaviour of a person. "Learning is a relatively permanent change in behaviour or behaviour potentiality that results from experience and cannot be attributed to temporary body states such as those induced by illness, fatigue or drugs" (Hergenhahn \& Olson, 2001, pp 6-7). Behaviourism in its context itself aims to produce behavioural changes in desired direction. In Skinner's experiment, he introduced behaviour modification known as Operant Conditioning (Skinner, $1938,1953)$, which has been widely applied in today's educational setting and immensely applied by educators during teaching process. The main objective of this set of therapy focuses on changing environmental events that are related to a person's behaviour. The example is by reinforced one's desired behaviours and ignore or give punishments to the undesired one. This operant behaviour therapy might sound easy to be carried out and applied, however it is not. Therapists who are responsible to make this therapy work always concerned about what people do and feel. Behaviour therapist configures what is done by two kinds of selective consequences, innate behaviour to natural selection and learned behaviour to operant reinforcement. For example, fear that is an innate behaviour is not solely a response of glands and smooth muscle, it is also a reduced probability of moving toward a feared object and a heightened probability of moving away from it. For this such of circumstances, it is called an operant side to emotion. Nevertheless, there is also operant side of anger, which is a learned behaviour. In this case, there is a significant probability of hurting someone and a reduced probability of acting to please. Feeling is something that is considered as bodily state resulted from respondent condition while bodily state resulted from operant conditioning, is called a state of mind. An operant is strengthened when a response has reinforcing consequences, but subsequent responses occur because of what had happened, not what is going to happen (Skinner, 1988). This explanation given by Skinner shows how operant therapy works in modifying one's behaviour. Positive and negative reinforcement that has been discussed earlier on is an example how operant can be strengthened. To summarize this therapy/technique in a simpler way, I tabulated it in the table 1.1 . 
DEVELOPMENT

Vol. 10, No. 1, 2021, E-ISSN: $2226-6348$ @ 2021 HRMARS

Table 1.1 Skinner operant therapy techniques

\begin{tabular}{|l|c|l|}
\hline Techniques & $\begin{array}{c}\text { Effect on } \\
\text { Behaviour }\end{array}$ & \multicolumn{1}{|c|}{ Examples } \\
\hline Positive reinforcement & Increase & $\begin{array}{l}\text { f5 given by teacher when done the homework, } \\
\text { merit marks, praise, sweets for participation in } \\
\text { class. }\end{array}$ \\
\hline Negative reinforcement & Increase & $\begin{array}{l}\text { f5 need to give to the teacher if failed to finish } \\
\text { homework given, } \\
\text { Withdrawal of threat of punishment if a pupil } \\
\text { behaves well in class. }\end{array}$ \\
\hline $\begin{array}{l}\text { Punishment - produce } \\
\text { something unpleasant }\end{array}$ & Decrease & $\begin{array}{l}\text { Give students a detention when they are not } \\
\text { behaving correctly in class. }\end{array}$ \\
\hline $\begin{array}{l}\text { Punishment - remove } \\
\text { something pleasant }\end{array}$ & Decrease & $\begin{array}{l}\text { Prevent child from participate in class activity } \\
\text { such as play games. }\end{array}$ \\
\hline
\end{tabular}

When discussed about this particular method, an important subject other than the students itself is the teacher whom responsible to implement this method in educational setting. Looking at the theory outlined, it might seems easy for the teacher to implement this idea in classroom for what we assume as related to behavioural issue. The real challenge is nevertheless, for a teacher to make all these outlined theory work by implementing reinforcement and punishment correctly according to the correct situation while targeting the desirable and undesirable behaviour within the child. Example for this could be explained in the situation below;

"A child is in a school classroom. When he is quiet (reading or drawing) the teacher pays no attention to him. He throws a ball of paper at another child. The teacher tells him off. He starts reading but after a while throws something again. The teacher pays attention to him. After a while he frequently throws things." (Greene and Hicks, 1984, pp 53).

Based on the above case, it is clear that the child finds a reward for himself instead of punishment as soon as the teacher tell him to stop because for him, he succeed in create a form of attention while doing that particular behaviour. He received an attention from his teacher after a repetitive behaviour was done and for him, this is what he wanted rather than sits quietly with no attention pays to him. Reinforcement or punishment is said to be implemented effectively by a teacher when; First, desirable behaviour being quiet is rewarded with praise by the teacher. Second, the teacher put an end to the disruption caused by the child efficiently and not to falls into the child's bait for the second time. This will actually provide a win-win situation when the situation can turn into the teacher give reward to the offending child and also the teacher shows his/her irritation to the child who caused disruption. With this, argument with the child who caused disruption would definitely be avoided. This scenario highlights the importance of teacher's role in managing class. Referring to Al-Ghazali's teaching that is more towards behaviourist approach, first, he said that, teachers should simplify the lesson. They should simplify the difficult concept that is hard for the student to grasp. This could be done by explaining, telling stories, praising and many other methods so that the teaching process can be done effectively and efficiently. 
Secondly, teachers need a proper planning in their teaching. Al-Ghazali stressed on the importance of planning and advised that teacher should do the preparation before teaching for effective teaching. Besides, with preparation, teachers will know what to expect and be prepared with what awaits them and know how to handle things.

For constructivism, Piaget (1952) did not explicitly relate his theory to education even though later researchers show his theory can be applied in both teaching and learning. It is also crucial to know that constructivism is not a theory about teaching, but a theory about learning instead. It is not something likes a 'cook book' where all the instruction is written inside and readers just have to follow the steps to get desirable result. There is no absolute technique from constructivist approach to teaching that can be applied directly. Most of the time, general principles of learning derived from constructivism can be helpful, however, sometimes it is not and as we rethink and reform our educational practices, we realized that;

- Rather than the result of development, learning itself is a development. It requires participation from the learner for the process to be carried out. Thus, teachers/educator need to allow their student to be an active learner by asking questions, generate their own hypotheses, and discuss as a group of community while the lesson take place.

- Disequilibrium/imbalance assists learning process. Errors done by the student should be seen as the result of learner making an effort to learn. It should not be avoided or minimized. Challenging, meaningful context needs to be offered to allow learners to explore and generate as many possibilities as they can, for both contradictory and affirming. Contradiction can be a subject to be explored and discussed and thus served as a platform for learner to improve.

- Reflective concept is the driving force of learning. Human constantly making meaning, organize their thought and generalize experiences in a representational form. Several methods such as journal writing, representation in multi-symbolic form and discusses connection across experiences allows reflection time for the learner.

- Thinking process is generated through dialogue within a community. The classroom needs to be seen as "community of discourse engaged in activity, reflection, and conversation" (Fosnot, 1989). The learners have the power and at the same time responsible to prove, justify, defend and communicate their own idea to the classroom community. As long as their ideas make sense to the community surrounding them, they can be accepted and the idea will be taken-as-shared.

- Activities and self-organization contribute to a successful learning process to the learner, which then lead towards the development of structures. While the meaning making process took place progressive structural shifts in perspective are constructed -in a sense "big ideas" (Schifter \& Fosnot, 1993).

\section{Conclusion}

For decades, there have been a plethora of literatures discussed about behaviourism and constructivism. These two learning theories brought up by great behaviourist and constructivist has contributed immensely in educational setting. Both are different in certain perspectives but 
still carry message or I shall say view that aims to give benefit to humankind and generate the ideal beings. Behaviourists see how the learning process occurs in person, originating from outside of a person. They proposed that outside influence plays an important role for the learning process to occur. Not only that, they view learning as changing the behaviour of individuals. This is in line with Imam Al-Ghazali words that his aim of education is to build a character of an individual so that he/she can differentiate between good and evils and eventually avoid from following the evil path. He added, character is bigger than temperance. The temperance exists in the character and the character can be changed through education. The whole idea of constructivism revolves around how character and therefore behaviour can be change in desired direction so that learning process reaches the idea of utopia and yield an ideal student. Constructivism on the other hand, is a post-structuralism psychological theory (Doll, 1993); theory that elucidates learning process occurs while the active learners interact with their surroundings. This is because learning is interpretive, repetitive and non-linear building process. It is the theory that emphasized on how learners make a meaning out of experiences they encountered along the journey of acquiring knowledge. It is a theory based on complexity models of evolution and development.

\section{Theoretical Contribution}

Both theories, constructivism and behaviourism deal with interactions with people either in changing one's behaviour to desired one or construct meanings from experiences. Both need interaction with people and cannot be done by own self. Educators are those who bear the responsibility to determine what this new paradigm brings to the practice of teaching. As educators made aware of individual learners' worldview differences, a much promising outcome may be yield in future.

\section{Funding}

This work was supported by the Universiti Putra Malaysia under Grant GP-IPS/2018/9654500

\section{References}

Applefield, J. M., Huber, R., \& Moallem, M. (2001). Constructivism in theory and practice: Toward a better understanding. The High School Journal, 84(2), 35.

Arifin, H. M. (1991). Ilmu Pendidikan Islam, Bumi Aksara, Jakarta, 103-104.

Al-abrasy, M. A. (1973). At-tarbiyah Al-Islamiyah Wa Falasifatuha, Egypt: Isa Al-Babi Al-Halabi, 3rd Printed, p.237.

Bigot, C. S. (1957), ilmu jiwa dan pendidikan, yogyakarta, chapter v charactereology.

Burns, S. (1995). Rapid changes require enhancement of adult learning. HR Monthly, 16-17.

Boyle, T. (1997). Design for multimedia learning. Prentice Hall Europe. Herdfordshire, UK, 67-83. Doll, W. (1993). A post-modern perspective on curriculum. New York: Teachers College Press.

Fosnot, C. T. (1989). Science education revisited: A defense of Piagetian constructivism. Journal for Research in Science Education, 39(9), 1189-1201.

Faris, N. A. (1962). The Book of Knowledge Being a Translation with notes of Kitab al-"Ilm of AlGhazzali"s Ihya' 'Ulum al-Din. Beirut, Lebanon: Islamic Book Service, New Delhi.

Greene, J., Hicks, C. (1984) "Basic Cognitive Processes: Open Guides to Psychology". Open 
INTERNATIONAL JOURNAL OF ACADEMIC RESEARCH IN PROGRESSIVE EDUCATION AND

DEVELOPMENT

Vol. 10, No. 1, 2021, E-ISSN: 2226-6348 @ 2021 HRMARS

University Press: Milton Keynes

Greening, T. (1998). Building the constructivist toolbox: An exploration of cognitive technologies. Educational Technology, 38 (2).

Hergenhahn, B. R., \& Olson, M. H. (2001). Introduction to Theories of Learning. (6 $6^{\text {th }}$ ed.) PrenticeHall, 6-7.

Piaget, J. (1948). The moral judgment of the child. (Orig. publ. 1932) Glencoe, III: Free Press.

Piaget, J., \& Cook, M. T. (1952). The origins of intelligence in children.

Piaget, J. (1970). Structuralism. New York: Basic Books.

Piaget, J. (1972). The child's conception of the world. Towota, NJ. Littlefield Adams (original work published 1926)

Piaget, J. (1973). Main Trends in Psychology. London: George Allen \& Unwin.

Laird, D. (1985). Approaches to training and development, Reading, Mass: Addison-Wesley.

Semple, A. (2000). Learning theories and their influence on the development and use of educational technologies. Australian Science Teachers Journal, 46(3), 21.

Schifter, D., \& Fosnot, C. T. (1993). Reconstructing mathematics education: Stories of teachers meeting the challenge of reform. New York: Teachers College Press.

Scallie, W. J. (2010). Al-Gazali Kitab sharh "aja"ib al- qalb. The Marvels of The Heart. Book 21 of the Ihya' 'Ulum Al-din. The Revival of The Religious Science Translated from the Arabic. (M. I. Hozien \& V. J. Turner, Eds.). USA: Fons Vitae.

Skinner, B. F. (1984). An Operant Analysis of Problem Solving. The Behavioural and Brain Sciences, 7, 583-613.

Skinner, B. F. (1938). The Behaviour of organisms: An experimental analysis. New York: AppletonCentury

Skinner, B. F. (1953). Science and human behaviour.

Skinner, B. F. (1988). Operant Side of Behavioural Therapy. Behaviour Therapy \& Experiment Psychiatry, 19(3), 171-179.

Vygotsky, L. S. (1978). Mind in Society. Cambridge, MA: Harvard University Press

Watson, J. B. (1913). Psychology as the behaviourist views it. Psychological Review, 20, 158-178.

Watson, J. B. (1930). Behaviourism (revised edition). University of Chicago Press.

Wadsworth, B. J. (2004). Piaget's theory of cognitive and affective development: Foundations of constructivism. Longman Publishing. 